\title{
PENERAPAN PRINSIP NEGARA HUKUM DI INDONESIA
}

\author{
Haposan Siallagan \\ Fakultas Hukum Universitas HKBP Nommensen Jln. Sutomo No. 4A Medan \\ E-mail: haposan.siallagan@yahoo.co.id
}

\begin{abstract}
ABSTRAK. Berdasarkan ketentuan UUD 1945 hasil perubahan, disebutkan dengan tegas bahwa negara Indonesia adalah negara hukum. Prinsip negara hukum Indonesia tidak merujuk secara langsung pada dua paham atau aliran berbeda tentang negara hukum, yaitu negara hukum dalam arti rechtsstaat dan negara hukum dalam arti the rule of law. Namun demikian, penerapan prinsip negara hukum Indonesia didasarkan pada unsur-unsur negara hukum secara umum, yaitu adanya upaya perlindungan terhadap hak asasi manusia, adanya pemisahan atau pembagian kekuasaan, adanya pelaksanaan kedaulatan rakyat, adanya penyelenggaraan pemerintahan yang didasarkan pada peraturan perundang-undangan yang berlaku dan adanya peradilan administrasi negara. Agar tercapai tujuan negara hukum Indonesia sebagaimana dicita-citakan dalam Pembukaan UUD 1945, maka seluruh unsur dimaksud harus diterapkan secara konsisten.
\end{abstract}

Kata kunci: negara hukum, UUD 1945, Indonesia.

\section{AMBIGUITY OF INDONESIA STATE LAW CONCEPT}

\begin{abstract}
Based on the 1945 results of the change, is mentioned that Indonesia is a country of law. Indonesia rule of law does not refer directly to the two streams different of the state of law, namely the state of law within the meaning of rechtsstaat and state law within the meaning of the rule of law. However, the application of the rule of law Indonesia is based on elements of the state of law in general, namely the protection of human rights, the separation or division of powers, the implementation of the sovereignty of the people, governance is based on legislation in force and judicial state administration. In order to achieve the country's goal of Indonesian law, as aspired to in the Preamble of the 1945 Constitution, all the elements in question must be applied consistently.
\end{abstract}

Key words: state of law, constitution 1945, Indonesia.

\section{PENDAHULUAN}

Perkembangan sistem ketatanegaraan sejumlah negara belakangan ini menunjukkan bahwa begitu banyak negara yang kemudian menjadikan konsepsi tentang negara hukum sebagai konsep ideal dalam membangun kehidupan berbangsa dan bernegara. Hal itu menunjukkan bahwa betapa sentralnya posisi dan kedudukan hukum dalam perjalanan kehidupan berbangsa dan bernegara, khususnya dalam rangka mengatur kehidupan suatu negara menjadi lebih baik. Hukum menjadi sesuatu yang sangat urgen untuk menata kehidupan manusia.

Sesungguhnya, konsepsi negara hukum sendiri sudah lama menjadi bahan perbincangan para ahli. Bahkan pada zaman Yunani Kuno, konsepsi negara hukum sudah mulai diperdebatkan dan dijadikan diskusi berkelanjutan sebagai salah satu landasan kehidupan manusia. Plato maupun Aristoteles pada masa kejayaannya sudah memandang negara hukum sebagai salah satu pembahasan yang cukup menarik serta diprediksi akan menjadi diskusi menarik di kemudian hari. Hal itu pun terbukti bahwa saat ini, konsep negara hukum selalu saja mendapat porsi pembahasan yang sangat menonjol dalam sistem ketatanegaraan suatu negara.

Hanya saja, pada saat awal munculnya pembahasan negara hukum, konsep dimaksud masih hanya ditujukan sebatas upaya atau perjuangan dalam rangka menentang kekuasaan raja yang begitu absolut. Artinya, cakrawala pemahaman tentang negara hukum ketika itu masih hanya terbatas pada upaya mengendalikan pergerakan kekuasaan raja yang begitu besar. Kala itu, kekuasaan suatu negara selalu bertumpu pada raja, sehingga kemudian sangat rentan melahirkan kesewenang-wenangan.

Atas dasar pertimbangan demikian, maka upaya membatasi kekuasaan raja menjadi sangat urgen demi masa depan dan eksisnya suatu negara. Tanpa adanya pembatasan kekuasaan raja, maka menjadi sangat sulit untuk mengontrol jalannya pemerintahan. Oleh sebab itu, prinsip utama negara hukum selalu dipandang sebagai upaya pembatasan kekuasaan para penguasa serta dalam rangka menjaga dan melindungi hak asasi manusia.

Sebagaimana dikemukakan Janpatar Simamora (2014:549), bahwa pada umumnya konsepsi tentang negara hukum selalu berkiblat pada dua tradisi hukum yang berbeda, yaitu common law system dan civil law system. Kedua sistem hukum tersebut menggunakan istilah yang berbeda pula, yaitu rechtsstaat dan the rule of law. Dalam sistem hukum Eropa Kontinental, istilah rechtsstaat juga disebut dengan istilah lain seperti concept of legality atau etat de droit. Adapun untuk istilah the rule of law menjadi populer setelah diterbitkannya buku $A V$. Dicey pada tahun 1885 dengan judul Introducion to Study of the Law of the Constitution. Kedua paham tersebut, yaitu rechtsstaat dan the rule of law memiliki latar belakang sistem hukum yang berbeda. Rechtsstaat diketaui muncul sebagai upaya 
menentang absolutism raja atau penguasa, yang sifatnya revolusioner dan bertumpu pada sistem hukum kontinental yang disebut civil law system. Sedangkan the rule of law dapat dikatakan berkembang secara evolusioner yang kemudian bertumpu atas sistem hukum commn law system.

Kedua sistem hukum dimaksud pada prinsipnya mengarah pada satu pemahaman dan pemaknaan utama, yaitu negara hukum. kedua sistem dimaksud sama-sama memandang hukum sebagai sarana efektif dalam menata kehidupan berbangsa dan bernegara. Namun demikian, terdapat perbedaan yang sangat nyata di antara keduanya.

Rechtsstaat misalnya, pada prinsipnya mengandung sejumlah ciri pokok di antaranya adanya perlindungan terhadap hak asasi manusia, adanya pemisahan atau pembagian kekuasaan lembaga negara dalam rangka menjamin pelaksanaan kekuasaan negara itu sendiri, serta adanya peradilan administrasi. Adapun the rule of law pada prinsipnya mengandung ciri pokok seperti adanya supremasi hukum, adanya persamaan kedudukan di hadapan hukum (equility before the law) serta adanya jaminan perlindungan hak asasi manusia.

Dilihat dari sejumlah ciri khas dimaksud, tampak dengan jelas adanya perbedaan di antara kedua sistem hukum dimaksud. Dalam negara hukum yang menganut rechtsstaat, terlihat dengan jelas bagaimana pentingnya peradilan administrasi sebagai salah satu alat pembeda dengan sistem hukum lainnya. Sementara dalam negara hukum yang menganut the rule of law, menempatkan pentingnya persamaan di hadapan hukum. namun demikian, kendati misalnya rechtsstaat tidak menegaskan adanya prinsip persamaan di hadapan hukum, bukan berarti bahwa hal tersebut dapat dimaknai bahwa negara hukum rechtsstaat tidak mengakui konsep persamaan di hadapan hukum.

Dalam catatan historis ketatanegaraan Indonesia, konsep negara hukum selalu ditegaskan dalam konstitusi. Kendati sejumlah konstitusi maupun UUD telah pernah mengalami pergantian maupun perubahan di tanah air, namun penegasan tentang negara Indonesia sebagai negara hukum selalu dilakukan dalam konstitusi. Hal tersebut menunjukkan bahwa bangsa Indonesia sendiri memandang betapa pentingnya konsep negara hukum dalam mengatur kehidupan berbangsa dan bernegara. Baik dalam UUD 1945 sebelum perubahan, Konstitusi RIS 1949 dan UUDS 1950 hingga berlakunya kembali UUD 1945 sampai dengan UUD 1945 hasil perubahan, konsep negara hukum selalu mendapat penekanan tersendiri dalam konstitusi.

Hanya saja, jika dilihat dari substansi pengaturannya, pemaknaan konsepsi negara hukum Indonesia saat ini kurang jelas seiring dengan tidak adanya penegasan akan negara hukum yang dianut Indonesia. Dalam UUD 1945 konsep negara hukum ditegaskan melalui Bagian Penjelasan, tepatnya pada Bagian Sistem Pemerintahan Negara. Menurut ketentuan tersebut ditegaskan bahwa sistem pemerintahan negara yang ditegaskan dalam Undang-Undang Dasar adalah Indonesia merupakan negara yang berdasar atas hukum (rechtsstaat). Negara Indonesia berdasar atas hukum (rechtsstaat), tidak berdasarkan kekuasaan belaka (machtsstaat).

Dengan adanya penegasan demikian, maka pemaknaan konsep negara hukum Indonesia ketika itu tidak menimbulkan pemaknaan ambigu, sebab ditemukan adanya penegasan tentang konsepsi negara hukum yang dianut, yaitu rechtsstaat. Namun hal sebaliknya justru terjadi pada UUD 1945 hasil perubahan, di mana penegasan negara hukum sebagaimana dituangkan dalam Pasal 1 ayat (3) UUD 1945 hasil perubahan tidak dibarengi dengan penjelasan lebih lanjut terkait dengan negara hukum mana sesungguhnya yang dianut Indonesia saat ini. Apakah negara hukum rechtsstaat atau the rule of law.

Bahkan sampai saat ini, belum ditemukan adanya regulasi yang menguatkan terkait dengan negara hukum apa sesungguhnya yang dianut oleh Indonesia. Oleh sebab itu, kiranya menjadi penting untuk diketahui bagaimana sesungguhnya penerapan prinsip negara hukum di Indonesia. Hal ini menjadi bahan diskusi yang sering mengemuka, baik di kalangan akademisi maupun praktisi hukum Indonesia belakangan ini. Sejalan dengan itu, penulis bermaksud melakukan penelaahan lebih lanjut terkait dengan bagaimana sesungguhnya konsep negara hukum yang dianut di Indonesia.

\section{METODE}

Penelitian ini menggunakan metode deskriptif analitis. Adapun penelitian yang bersifat deskriptif analitis adalah penelitian yang bertujuan atau dimaksudkan untuk menguraikan atau mendeskripsikan atau memberikan gambaran secara sistematis, faktual serta akurat mengenai suatu populasi atau daerah tertentu terkait dengan sifat-sifat atau faktor-faktor tertentu (Bambang Sunggono, 1997:3). Adapun jenis penelitian ini adalah yuridis normatif dengan mengkaji bahan hukum atau bahan kepustakaan sebagai kajian utama. Terkait dengan pendekatan yang dilakukan adalah pendekatan yuridis serta pendekatan historis sesuai dengan kebutuhan. Analisis bahan hukum dilakukan dengan cara mensistematisasi bahanbahan hukum yang ada dan kemudian dianalisis secara kualitatif. Berdasarkan hasil analisis, kemudian disusun suatu simpulan sebagai hasil akhir dari penelitian.

\section{HASIL DAN PEMBAHASAN}

\section{Istilah Negara Hukum}

Peristilahan tentang negara hukum sudah begitu populer dalam kepustakaan Indonesia. Bukan hanya di kalangan ahli hukum, masyarakat umum juga sudah begitu mengenal istilah dimaksud. Adapun istilah negara 
hukum pada terminologi negara-negara di Eropa dan Amerika, menggunakan istilah yang berbeda-beda. Di Jerman dan Belanda misalnya, digunakan istilah rechtsstaat sebagaimana istilah dimaksud juga pernah diberlakukan atau dikenal di Indonesia. Di Prancis digunakan istilah etat de droit. Istilah estado de derecho dipakai di Spanyol dan istilah stato di diritto digunakan di Italia. Dalam terminologi Inggris dikenal dengan ungkapan the state according to law atau accroding to the rule of law (Allan R. Brewer and Carias, 1989:7).

Lebih lanjut dikemukakan bahwa istilah-istilah seperti etat de droit, estado de derecho, stato di diritto atau rechtsstaat yang digunakan dalam paham atau konsep Eropa Kontinental dan Amerika Latin adalah merupakan istilah-istilah yang tidak mempunyai padanan kata yang tepat dalam sistem hukum Inggris, meskipun ungkapan legal state atau state according to law atau the rule of law mencoba mengungkapkan suatu ide yang serupa.

Selain istilah rechtsstaat, istilah lain yang juga sangat populer di Indonesia adalah the rule of law, yang juga digunakan untuk maksud negara hukum. Notohamidjojo (1970:27) menggunakan kata-kata "... maka timbul juga istilah negara hukum atau rechtsstaat". Kemudian, Djokosoetono mengatakan bahwa negara hukum yang demokratis sesungguhnya istilah ini adalah salah, sebab kalau kita hilangkan democratische rechtsstaat, yang penting dan primair adalah rechtsstaat (Padmo Wahyono, 1984:67).

Muhammad Yamin (1982:72) menggunakan kata negara hukum sama dengan rechtsstaat atau government of law. Jelasnya Yamin menyatakan bahwa: "Republik Indonesia ialah negara hukum (rechtsstaat, government of law) tempat keadilan yang tertulis berlaku, bukanlah negara polisi atau negara militer, tempat polisi dan prajurit memegang pemerintah dan keadilan, bukanlah pula negara kekuasaan (macthtsstaat) tempat tenaga senjata dan kekuatan badan melakukan sewenang-wenang." ( kursif penulis)."

Dengan demikian dalam kepustakaan Indonesia selain istilah rechtsstaat juga dikenal istilah the rule of law, yang artinya juga negara hukum. Sejalan dengan hal itu, Mauro Capelletti (1971:42) menggunakan istilah rechtsstaat sama dengan the rule of law, dalam kata-katanya sebagai berikut: “...it has since come to be consident by many as essential to the rule of law (rechtsstaat) anywhere." Demikian pula Sunaryati Hartono (1976:35), menggunakan istilah negara hukum yang membawa keadilan bagi seluruh rakyat yang bersangkutan, penegakan the rule of law itu harus dalam arti materiil."

Ismail Suny (1982:123) juga menggunakan istilah the rule of law dalam pengertian negara hukum, dalam membahas pelaksanaan demokrasi terpimpin, dengan menggunakan kata-kata:”... pelaksanaan demokrasi terpimpin adalah dimana kepastian hukum tidak terdapat dalam arti sepenuhnya di negeri kita, that the rule of law absent in Indonesia, negara kita bukan merupakan negara hukum, ...." Dalam hal yang sama juga digunakan oleh Sudargo Gautama (1983:3), dalam kata-katanya: “... dalam satu negara hukum, terdapat pembatasan kekuasaan negara terhadap perseorangan. Negara tidak maha kuasa, tidak bertindak sewenang-wenang. Tindakan-tindakan negara terhadap warganya dibatasi oleh hukum. Inilah apa yang oleh ahli hukum Inggris dikenal sebagai rule of law."

Moh. Kusnardi dan Harmaily Ibrahim (1988:161) dengan tegas menyatakan bahwa di Inggris sebutan untuk negara hukum (rechtsstaat) adalah the rule of law, sedangkan di Amerika Serikat disebut sebagai "government of law, but no man". Kendati begitu banyak peristilahan yang mengemuka terkait negara hukum, namun sesungguhnya seluruh istilah dimaksud mengarah pada dua istilah pokok, yaitu rechtsstaat dan the rule of law. Beragam istilah tersebut selalu dirujuk kepada salah satu istilah pokok dimaksud. Dalam perjalanannya kemudian, sekalipun pemikiran tentang negara hukum sudah lama mengemuka, namun fakta menunjukkan bahwa istilah tersebut mulai populer di Benua Eropa sejak abad XIX. Setelah itu, perkembangan tentang negara hukum terus mengalami dinamika yang cukup signifikan sampai saat ini. Bahkan kemudian banyak negara di dunia yang menjadikan negara hukum sebagai konsep utama dalam kehidupan berbangsa dan bernegara.

\section{Konsep Eropa Kontinental tentang Negara Hukum (Rechtsstaat)}

Pembahasan konsep eropa kontinental tentang negara hukum atau rechtsstaat dijadikan sebagai salah satu topik dalam penulisan ini dikarenakan mengingat sejarahnya, Indonesia pernah menganut prinsip dimaksud dalam konstitusi atau UUD yang pernah berlaku di Indonesia. Pemikiran tentang negara hukum di Eropa Kontinental merupakan reaksi terhadap absolutisme yang hampir menyeluruh pada pemerintahan raja-raja di Benua Eropa. Paham rechtsstaat mulai populer sejak abad XIX, yang lahir dari suatu perjuangan terhadap absolutisme sehingga sifatnya revolusioner, yang bertumpu pada suatu sistem hukum kontinental yang disebut civil law. Ciri negara hukum pada masa itu dilukiskan sebagai negara penjaga malam (nachtwakersstaat), (Muntoha, 2009:384) tugas pemerintah dibatasi pada mempertahankan ketertiban umum dan keamanan (de openbare orde en veiligheid) (P.de Haan, Th.G Druksteen, R. Fernhout, 1986:8) Kemudian, Immanuel Kant, seorang yang berkebangsaan Jerman dikenal sebagai pemikir negara hukum yang sangat dominan di Eropa Kontinental.

Kant yang hidup antara tahun 1724-1804, yang lahir di Prusia Timur-Jerman, dalam bukunya Methaphysiche Ansfangsgrunde der Rechtslehre, mengemukakan konsep negara polizei staat atau negara polisi, dan pihak yang beraksi terhadap polizei staat adalah orang-orang kaya dan pandai, yang disebut kaum borjuis liberal (Harol H Titus, 1984:151). 
Kant mengemukakan paham negara hukum dalam arti sempit, yang menempatkan fungsi recht dan staat, hanya sebagai alat perlindungan hak-hak individual dan kekuasaan negara diartikan secara pasif, yang bertugas sebagai pemelihara ketertiban dan kemanan masyarakat. Sifat liberal negara hukum abad ke-19 di Eropa Kontinental, bertumpu pada liberty (vrijheid) dan asas demokrasi bertumpu pada equality (gelijkheid). Menurut Kant, liberty merupakan suatu kondisi yang memungkinkan mewujudkan kehendak secara bebas dan hanya dibatasi seperlunya untuk menjamin kehidupan bersama secara damai antara kehendak bebas individu dengan kehendak bebas bersama yang lain.

Dalam perkembangannya kemudian, dapat diketahui bahwa ciri-ciri negara hukum abad XIX, yaitu: adanya UUD atau konstitusi yang memuat ketentuan tertulis yang mengikat tentang hubungan antara pemerintah dan rakyat, adanya pemisahan kekuasaan, dan tindakan pemerintah harus berdasarkan atas undang-undang dan terjaminnya hak dasar atau hak-hak kebebasan rakyat.

Dari ciri-ciri di atas menunjukkan secara jelas bahwa dalam sebuah negara hukum, adanya UUD harus dapat memberikan jaminan konstitusional terhadap kebebasan dan persamaan. Pentingnya pemisahan kekuasaan supaya terhindar dari penumpukan kekuasaan dalam satu tangan, yang sering kali cenderung kepada penyalahgunaan kekuasaan dan kesewenang-wenangan. Dengan adanya pemisahan kekuasaan berarti juga sebagai jaminan terhadap terciptanya kekuasaan kehakiman yang merdeka terhadap kekuasaan lain.

Kekuasaan membentuk undang-undang yang dikaitkan dengan parlemen, dimaksudkan untuk menjamin bahwa hukum yang dibuat sesuai dengan kehendak rakyat. Hal tersebut dimaksudkan untuk mencegah terjadinya kesewenang-wenangan dalam tindakan pemerintah yang dapat melanggar hak-hak kebebasan dan persamaan terhadap rakyat.

Dalam perkembangan kemudian, paham negara hukum semacam ini dianggap kurang memuaskan, maka muncul pemikiran untuk memperbaiki paham Kant tersebut, yaitu dikenal dengan paham negara hukum formal. Sarjana yang mengembangkan faham tersebut adalah Frederich Julius Stahl. Stahl (Padmo Wahjono, 1989: 151) dalam usahanya menyempurnakan paham negara hukum liberal, mengatakan paham negara hukum formal, dengan unsur-unsur utamanya, yaitu: mengakui dan melindungi hak-hak asasi manusia; untuk melindungi terhadap hak-hak asasi tersebut maka penyelenggaraan negara harus berdasarkan atas teori trias politica; dalam menjalankan tugasnya, pemerintah harus berdasarkan atas undang-undang; jika dalam menjalankan tugasnya berdasarkan undang-undang pemerintah masih melanggar hak-hak asasi, maka ada pengadilan administrasi yang akan menyelesaikannya.
Unsur-unsur negara hukum formal yang dikemukakan oleh Stahl tersebut bertujuan untuk melindungi hak-hak asasi dengan cara membatasi dan mengawasi penyelenggaraan kekuasaan negara dengan undang-undang. Negara tidak boleh menyimpang atau memperluas penyelenggaraan kekuasaan negara. Padahal dalam kenyataan bahwa pembuat undang-undang tidak mungkin dapat memperkirakan atau mengatur seluruhnya apa yang akan terjadi dikemudian hari. Pembatasan yang ketat telah mempersempit ruang gerak pemerintah dalam menjalankan kekuasaan negara.

Dalam perkembangan selanjutnya, pada abad $\mathrm{XX}$, paham rechtsstaat mengalami penyempurnaan, dengan mendapat perhatian para pemikir dari benua Eropa, di antaranya Paul Scholten yang membedakan tingkatan antara asas dan aspek negara hukum. Unsur yang dianggap penting dinamakannya dengan asas dan unsur yang merupakan turunannya disebut aspek. Asas negara hukum menurut paham Scholten adalah (a) ada hak warga terhadap negara, yang mengandung dua aspek: pertama, hak individu pada prinsipnya berada di luar wewenang negara; kedua, pembatasan terhadap hak tersebut hanyalah dengan ketentuan undang-undang, berupa peraturan yang berlaku umum; (b) adanya pemisahan kekuasaan. Scholten, dengan mengikuti Montesquieu mengemukakan tiga kekuasaan negara yang harus dipisah satu sama lain, yaitu kekuasaan pembentuk undang-undang, kekuasaan melaksanakan undang-undang dan kekuasaan mengadili.

Kini, dalam konsep rechtsstaat yang lebih luas, tugas pemerintahan tidak sebatas pengertian sebagaimana pada abad XIX. Dalam pengertian modern menuntut pemerintah untuk mewujudkan kesejahteraan sosial. Dalam negara hukum sosial, negara atau pemerintah hanya melakukan wewenang, tugas dan tanggung jawab menjaga keamanan dan ketertiban, tetapi memikul tanggung-jawab yang lebih luas, yaitu mewujudkan kesejahteraan dan keadilan sosial bagi seluruh rakyatnya.

Selanjutnya, jika dibandingkan dengan prinsip negara hukum lainnya, dikenal adanya negara dengan sistem hukum Anglo Saxon yang menggunakan istilah rule of law. Istilah rule of law tersebut pada dasarnya merupakan ungkapan yang sama artinya dengan apa yang oleh sistem hukum Eropa Kontinental disebut dengan istilah rechtsstaat. Namun demikian, mungkin ada perbedaan sejarah yang melatar-belakangi lahirnya kedua sistem tersebut. Sistem Eropa Kontinental muncul sebagai suatu sistem yang rasional dan revolusioner dalam menentang absolutisme, sementara sistem Anglo Saxon atau the rule of law berkembang secara evolusioner.

Perbedaan demikian disebabkan karena latarbelakang kakuasaan raja. Pada zaman Romawi, kekuasaan yang menonjol dari raja ialah menbuat peraturan melalui keputusan-keputusan raja. Kekuasaan itu kemudian dilimpahkan atau di delegasikan kepada pejabat-pejabat 
pemerintah lainnya, sehingga pejabat-pejabat pemerintah membuat peraturan-peraturan bagi hakim tentang bagaimana memutus suatu sengketa. Begitu besarnya peranan pemerintah atau administrasi negara sehingga dalam sistem Kontinental muncul cabang hukum yang disebut droit administratif. Sebaliknya dalam sistem Anglo Saxon, kekuasaan raja yang utama adalah mengadili. Peradilan oleh raja kemudian berkembang menjadi suatu sistem peradilan, sehingga hakim-hakim peradilan adalah delegasi dari raja, tetapi bukan melaksanakan kehendak raja.

Hakim harus memutus perkara berdasarkan kebiasaan umum. Dengan demikian, pada sistem Eropah Kontinental mengarah kepada bertambah besarnya peranan peradilan dan para hakim. Atas dasar itu dalam sistem Kontinental perkembangannya mengarah kepada langkah-langkah untuk membatasi kekuasaan pejabat pemerintah, sedangkan dalam sistem Anglo Saxon mengarah kepada langkah-langkah untuk peradilan yang adil atau tidak memihak dari tindakan yang sewenangwenang.

Menurut A.V.Dicey, setidaknya terdapat tiga unsur utama dalam paham the rule of law. Ketiga unsur utama dimaksud, yaitu: supremasi aturan-aturan hukum atau dengan kata lain keunggulan mutlak hukum, kedudukan yang sama di muka hukum atau sering juga disebut dengan istilah persamaan di hadapan hukum, dan terjaminnya hak asasi manusia dalam konstitusi serta oleh lembaga peradilan. Dalam paham the rule of law, hukum konstitusi bukanlah sumber, tetapi merupakan konsekuensi dari hak-hak individu yang dirumuskan dan ditegaskan oleh pengadilan.

Pandangan Dicey tersebut sering juga dikatakan sebagai pandangan murni dan sempit, karena dari ketiga pengertian dasar yang diketengahkannya tentang the rule of law, intinya adalah common law sebagai dasar perlindungan kebebasan individu terhadap kesewenangwenangan penguasa. Perlindungan common law hanya dapat meluas kepada kebebasan pribadi tertentu seperti kebebasan berbicara, tetapi tidak dapat menjamin kesejahteraan ekonomi atau sosial warganegara seperti perlindungan fisik yang baik, memiliki rumah yang layak, pendidikan, pemberian jaminan sosial atau lingkungan yang layak dan lain sebagainya. Oleh sebab itu, dalam hal ini negara hanya terbatas dalam pengertian negara hukum formal, yaitu negara yang bersifat pasih, bukan proaktif. Sifat tersebut tidak terlepas dari fungsi negara yang hanya menjalankan dan taat pada apa yang tertuang dalam konstitusi negara itu sendiri.

\section{Negara Hukum Indonesia}

Istilah negara hukum Indonesia sering dipadankan dengan rechtsstaat dan juga istilah the rule of law. Jika dilihat dari sejumlah konstitusi yang pernah berlaku di Indonesia, dapat dikatakan bahwa semua konstitusi dimaksud selalu menegaskan bangsa Indonesia sebagai negara hukum. Terkait dengan hal itu, istilah yang digunakan dalam UUD 1945 sebelum perubahan adalah "Negara yang berdasarkan atas hukum (rechtsstaat)". Di samping itu juga, dalam rangka menunjukkan ciri khas bangsa Indonesia, juga dikenal istilah negara hukum dengan menambah atribut Pancasila sehingga atas dasar itu, maka kemudian sering disebut sebagai negara hukum Pancasila.

Selanjutnya, dalam Konstitusi RIS 1949, istilah negara hukum disebutkan secara tegas, baik dalam Mukadimah maupun di dalam Batang Tubuhnya. Dalam alinea ke 4 Mukadimah Konstitusi RIS, ditegaskan bahwa "Untuk mewujudkan kebahagiaan kesejahteraan, perdamaian dan kemerdekaan dalam masyarakat dan negara hukum Indonesia Merdeka yang berdaulat sempurna". Dalam Pasal 1 ayat (1) dipertegas lagi bahwa "Republik Indonesia Serikat yang merdeka dan berdaulat ialah suatu negara hukum yang demokrasi dan berbentuk federasi." Hal itu menunjukkan bahwa konsepsi negara hukum selalu dijadikan dasar dalam membangun kehidupan suatu negara.

Hal yang sama dapat juga dilihat dalam UUDS 1950, dimana istilah negara hukum secara jelas dicantumkan dalam Mukadimah dan Batang Tubuh. Alinea ke 4 Mukadimah UUD 1950 berbunyi: "Maka demi ini kami menyusun kemerdekaan kami itu dalam suatu piagam Negara yang berbentuk republik kesatuan, berdasarkan pengakuan keTuhanan Yang Maha Esa, peri-kemanusiaan, kebangsaan, kerakyatan dan keadilan sosial, untuk mewujudkan kebahagiaan, kesejahteraan, perdamaian dan kemerdekaan dalam masyarakat dan Negara hukum Indonesia Merdeka yang berdaulat sempurna". Kemudian dalam Bab I bagian I, Pasal 1 ayat (1) UUDS 1950, ditegaskan lagi bahwa: "Republik Indonesia yang merdeka dan berdaulat ialah suatu negara hukum yang demokratis dan berbentuk kesatuan”.

Jika dilihat dari kedua UUD tersebut, tampak dengan jelas bahwa istilah negara hukum dicantumkan secara jelas dan tegas. Kedua UUD itu menggunakan pengertian negara hukum dikaitkan atau dihubungkan dengan pengertian demokratis, sehingga menjadi rumusan negara hukum yang demokratis.

Selanjutnya, dalam UUD 1945 sebelum perubahan, khususnya sebagai perubahan ketiga yang dilakukan pada tahun 2001, baik dalam Pembukaan maupun Batang Tubuh atau pasal-pasalnya, tidak ditemukan rumusan atau istilah negara hukum. Istilah negara hukum hanya terdapat dalam Bagian Penjelasan, yaitu "Sistem Pemerintahan Negara" disebutkan bahwa "Indonesia ialah negara yang berdasarkan atas hukum (rechtsstaat)". Menurut penulis, rumusan atau ungkapan negara yang berdasarkan atas hukum hampir menyerupai terminologi yang dikenal di Inggris atau Anglo Saxon, yaitu seperti the state according to law, sedangkan istilah rechtsstaat di antara tanda kurung dalam Penjelasan UUD 1945 di atas, merupakan istilah atau rumusan yang 
sering digunakan di negara-negara Eropa Kontinental, seperti Jerman dan Belanda. Oleh sebab itu, maka dapat dikemukakan bahwa penggunaan kedua ungkapan tersebut dalam Penjelasan UUD 1945, menandakan bahwa substansi negara hukum Indonesia tidak terlepas dari pengaruh paham Anglo Saxon dan Eropah Kontinental.

Kini, dalam UUD 1945 setelah perubahan, penegasan negara hukum bagi Indonesia dilakukan melalui Pasal 1 ayat (3) UUD 1945. Namun demikian, tidak ditemukan penjelasan terkait dengan negara hukum mana sesungguhnya yang bangsa Indonesia saat ini. Apakah negara hukum dalam arti rechtsstaat atau negara hukum dalam arti the rule of law atau justru merupakan negara hukum dengan ciri khas tersendiri.

Sebagaimana diketahui bahwa secara umum, lazimnya konsep negara hukum selalu merujuk pada dua aliran utama, yaitu negara hukum dalam arti rechtsstaat dan negara hukum dalam arti the rule oflaw. Namun dalam UUD 1945 setelah perubahan, penegasan konsep negara hukum bagi Indonesia tidak dibarengi dengan penjelasan lanjutan terkait dengan paham negara hukum yang dianut. Hal demikian pada prinsipnya mengakibatkan paham negara hukum yang dianut Indonesia menjadi kurang mengandung kejelasan serta kepastian. Belum lagi ditambah dengan apa yang dikemukakan Dayanto (2013:498) bahwa pembangunan hukum pasca reformasi terkesan tambal sulam.

Penerapan prinsip negara hukum di Indonesia dapat dikatakan dijalankan tanpa berpatokan secara langsung pada prinsip rechtsstaat atau rule of law. Janpatar Simamora (2016:26) mengemukakan bahwa terwujudnya negara hukum sebagaimana yang dicitacitakan dalam UUD 1945 akan dapat direalisasikan bila seluruh proses penyelenggaraan pemerintahan atau negara benar-benar didasarkan pada kaidah-kaidah yang tertuang dalam konstitusi itu sendiri.

Negara hukum Indonesia memiliki ciri-ciri tersendiri yang barangkali berbeda dengan negara hukum yang diterapkan di berbagai negara. Hanya saja, untuk prinsip umumnya, seperti adanya upaya perlindungan terhadap hak asasi manusia, adanya pemisahan atau pembagian kekuasaan, adanya pelaksanaan kedaulatan rakyat, adanya penyelenggaraan pemerintahan yang didasarkan pada peraturan perundang-undangan yang berlaku dan adanya peradilan administrasi negara masih tetap digunakan sebagai dasar dalam mewujudkan negara hukum di Indonesia.

Berdasarkan pelaksanaannya kemudiannya, sejumlah unsur penting tersebut diwujudkan dengan baik. Terkait dengan perlindungan hak asasi manusia, UUD 1945 setelah perubahan cukup mengakomodir masalah hak asasi manusia secara lengkap. Bahkan dapat dikatakan jauh lebih lengkap dari pengaturan yang terdapat dalam konstitusi yang pernah berlaku sebelumnya.
Demikian juga halnya dengan pemisahan atau pembagian kekuasaan, dilakukan melalui sejumlah lembaga negara yang diatur dalam UUD. Presiden menjalankan kekuasaan eksekutif, DPR dan DPD menjalankan kekuasaan legislatif serta adanya MA dan MK sebagai pelaksana kekuasaan kehakiman atau kekuasaan yudikatif (Janpatar Simamora, 2015:332). Keberadaan lembaga-lembaga negara tersebut diatur secara jelas dan tegas untuk menjalankan kekuasaan negara secara terpisah. Namun demikian dalam pelaksanaannya, kendati disebut terpisah, masing-masing lembaga negara saling melakukan pengawasan sesuai dengan kewenangan yang dimiliki demi terciptanya fungsi kontrol terhadap sesama lembaga negara.

Terkaitdenganunsurberikutnya, yaitupelaksanaan kedaulatan rakyat, unsur tersebut juga diterapkan secara langsung di Indonesia. Dilakukannya proses pemilihan secara langsung terhadap presiden dan wakil presiden serta para kepala daerah cukup menunjukkan bahwa Indonesia sangat menunjung tinggi pelaksanaan kedaulatan rakyat. Berdasarkan sistem demokrasi yang dijalankan di Indonesia, rakyat merupakan pemegang kedaulatan tertinggi. Bahkan dilihat dari model pelaksanaan demokrasi secara langsung di Indonesia, dapat dikatakan bahwa Indonesia merupakan salah satu negara yang paling demokratis dalam menjalankan dan merealisasikan kedaulatan rakyat.

Selanjutnya, terkait dengan unsur penyelenggaraan pemerintahan negara yang didasarkan pada peraturan perundang-undangan atau didasarkan pada hukum yang berlaku, hal tersebut dapat dilihat dari pelaksanaan kekuasaan negara yang selalu dilandaskan pada aturan yang sudah ada sebelumnya. Setiap aktivitas pemerintahan tidak dimungkinkan dijalankan tanpa adanya aturan hukum yang menjadi acuan dan dasar pelaksanaannya. Dalam konteks ini, sangat terlihat dengan jelas bagaimana hukum dijadikan sebagai dasar dalam menata kehidupan berbangsa dan bernegara.

Selain itu, perwujudan unsur negara hukum berikutnya adalah dapat dilihat dari adanya peradilan tata usaha negara sebagai jalan dan sarana dalam rangka melindungi kepentingan individu dalam masyarakat dari pelaksanaan kekuasaan negara oleh pemerintah. Oleh sebab itu, adanya peradilan tata usaha negara pada prinsipnya dimaksudkan untuk melindungi kepentingan individu dalam masyarakat atas pelaksanaan kekuasaan negara atau pemerintahan.

Dilihat dari sejumlah unsur tersebut, dapat ditegaskan bahwa penerapan prinsip negara hukum Indonesia didasarkan pada prinsip tersendiri yang barangkali tidak selalu sejalan secara utuh dengan prinsip-prinsip negara hukum sebagaimana dikenal pada masa awal lahirnya konsep negara hukum. Hal demikian dapat dimaknai sebagai bentuk dinamika atau perkembangan perwujudan negara hukum dalam 
tataran kekinian. Bagaimanapun juga bahwa prinsip negara hukum akan selalu mengalami perkembangan dari waktu ke waktu sesuai dengan kebutuhan dan perkembangan yang dialami oleh suatu negara.

Seiring dengan adanya penerapan negara hukum dengan prinsip tersendiri di Indonesia, tentu sangat diharapkan agar pelaksanaan negara hukum itu sendiri benar-benar berjalan sesuai dengan unsur-unsur yang terkandung dalam prinsip negara hukum. Penerapan negara hukum sangat membutuhkan konsistensi agar kemudian dapat berjalan dengan baik serta mampu mencapai tujuan negara hukum itu sendiri.

\section{SIMPULAN}

Didasarkan pada uraian tersebut di atas, cukup terlihat dengan jelas bahwa penerapan prinsip negara hukum di Indonesia tidak merujuk secara langsung terhadap dua aliran negara hukum, yaitu rechtsstaat maupun rule of law, namun dijalankan berdasarkan prinsip negara hukum dengan ciri tersendiri melalui elaborasi prinsip negara hukum pada umumnya, yaitu adanya perlindungan hak asasi manusia, adanya pemisahan atau pembagian kekuasaan, adanya pelaksanaan kedaulatan rakyat, adanya penyelenggaraan pemerintahan yang didasarkan pada peraturan perundang-undangan yang berlaku dan adanya peradilan administrasi negara.

Dalam rangka memaksimalkan penerapan prinsip negara hukum Indonesia, maka kiranya dalam setiap pelaksanaannya dapat dijalankan secara konsisten. Melalui konsistensi penerapan prinsip negara hukum bagi Indonesia, akan dapat terwujud tujuan negara hukum yang dikehendaki bangsa Indonesia itu sendiri. Negara hukum bukan hanya urgen dalam tataran konsep, namun sangat urgen dalam tataran praktik. Oleh sebab itu, konsistensi penerapannnya menjadi sangat dibutuhkan dan bahkan merupakan suatu keharusan agar membawa manfaat besar bagi kehidupan berbangsa dan bernegara.

\section{DAFTAR PUSTAKA}

Allan R.Brewer-Carias. 1989, Judicial Review in Comparative Law, Cambridge: Cambridge University Press.

Capeleeti, Mauro, 1971, Judicial Review in the Contemporary World, New York: The BobbsMerrill Company, Inc.

Dayanto, 2013, Rekonstruksi Paradigma Pembangunan Negara Hukum Indonesia Berbasis Pancasila,
Jurnal Dinamika Hukum, Vol. 13 No. 3, Purwokerto: FH Unsoed.

Gautama, Sudarso. 1983, Pengertian Negara Hukum, Bandung: Alumni.

Haan, P. de, Druksteen, Th.G., Fernhout, R., 1986. Bestuursrecht in de Sociale Rechtsstaat, Deel I, Kluwer - Deventer.

Hartono, Sunaryati. 1976, Apakah the Rule of Law, Bandung: Alumni.

Kusnardi, Moh. dan Ibrahim, Harmaily. 1998. Pengantar Hukum Tata Negara Indonesia, Jakarta: Pusat Studi Hukum Tata Negara Fakultas Hukum UI.

Muntoha, 2009, Demokrasi dan Negara Hukum, Jurnal Hukum, Vol. 16 No. 3, Yogyakarta: FH UII.

Notohamidjojo, O. 1970. Makna Negara Hukum, Jakarta: Badan Penerbit Kristen, 1970.

Simamora, Janpatar. 2016, Considering Centralization of Judicial Review Authority in Indonesia Constitutional System, IOSR Journal Of Humanities And Social Science (IOSR-JHSS) Vol. 21, Issue 2, Ver. V (Feb. 2016) PP 26-32.

Simamora, Janpatar. 2015, Comparison of Constitutional Court Authority Between Indonesia and South Korea, Journal of Dinamika Hukum, Vol. 15 No. 3 September 2015, Purwokerto: FH Unsoed.

Simamora, Janpatar. 2014, Tafsir Makna Negara Hukum dalam Perspektif Undang-Undang Dasar Negara Republik Indonesia, Jurnal Dinamika Hukum, Vol. 14 No. 3 September 2014, Purwokerto: FH Unsoed.

Sunggono, Bambang, 1997. Metode Penelitian Hukum, Jakarta: RajaGrafindo Persada.

Suny, Ismail. 1982. Mencari Keadilan, Jakarta: Ghalia Indonesia, 1982.

Titus, Harold H., (et.al.) 1984. Living Issues In Philosophy, alih bahasa oleh H.M.Rasjidi, Persoalan-persoalan Filsafat, Jakarta: Bulan Bintang.

Wahjono, Padmo. 1989. Pembangunan Hukum di Indonesia, Jakarta: In - Hill Co., 1984. Guru Pinandita, Jakarta: Badan Penerbit Fakultas Ekonomi Universitas Indonesia.

Yamin, Muhammad. 1982. Proklamasi dan Konstitusi Republik Indonesia, Jakarta: Ghalia Indonesia. 